Modelling for Added Value 
Springer-Verlag London Ltd. 
Macredie, Paul, Anketell, Lehaney and Warwick (Eds)

\section{Modelling for Added Value}

With 39 Figures 
Robert Macredie, BSc(Hons), $\mathrm{PhD}$

Ray Paul, BSc, MSc, PhD

Department of Information Systems and Computing, Brunel University, Uxbridge UB8 3PH, UK

Dervarajan Anketell, DipTech, MSc

Anketell Management Services Ltd., 608 Kingston Road, Raynes Park, London SW20 8DN, UK

Brian Lehaney, BA, MSc

Shamim Warwick, BSc, MSc

Department of Computing, University of Luton, Luton, UK

\section{ISBN 978-3-540-76108-2}

British Library Cataloguing in Publication Data

Modelling for added value

1. Information storage and retrieval systems 2 . Database management

3. Databases

I. Macredie, Robert

$005.7^{\prime} 4$

ISBN 978-3-540-76108-2

Library of Congress Cataloging-in-Publication Data

Modelling for added value / Macredie ... [et al.], eds.

p. $\mathrm{cm}$.

Includes bibliographical references and index.

\section{ISBN 978-3-540-76108-2 ISBN 978-1-4471-0601-2 (eBook)}

DOI 10.1007/978-1-4471-0601-2

1. Management information systems. 2. Decision support systems.

I. Macredie, Robert, 1968-

T58.6.M6123 1998 98-3911

$658.4^{\prime} 0352--\mathrm{dc} 21$

CIP

Apart from any fair dealing for the purposes of research or private study, or criticism or review, as permitted under the Copyright, Designs and Patents Act 1988, this publication may only be reproduced, stored or transmitted, in any form or by any means, with the prior permission in writing of the publishers, or in the case of reprographic reproduction in accordance with the terms of licences issued by the Copyright Licensing Agency. Enquiries concerning reproduction outside those terms should be sent to the publishers.

(c) Springer-Verlag London 1998

Originally published by Springer-Verlag London Limited in 1998

The use of registered names, trademarks etc. in this publication does not imply, even in the absence of a specific statement, that such names are exempt from the relevant laws and regulations and therefore free for general use.

The publisher makes no representation, express or implied, with regard to the accuracy of the information contained in this book and cannot accept any legal responsibility or liability for any errors or omissions that may be made.

Typesetting: Gray Publishing, Tunbridge Wells, Kent

34/3830-543210 Printed on acid-free paper 


\section{Contents}

List of Contributors . . . . . . . . . . . . . . vii

\section{Theme I: Modelling for Evaluation and Change}

1 Modelling for Change: An Information Systems Perspective on Change Management Models Robert D. Macredie, Carl Sandom and Ray J. Paul . . . . . . . . 3

2 Information Systems as Powerful Forces of Change D. (Rajan) Anketell . . . . . . . . . . . . . . . . 17

3 How the Open University Uses Information Technology to Provide Distance Learning in a Competitive Market Anthony Lucas-Smith. . . . . . . . . . . . . . . . . . . 27

4 Information Technology as a Tool for Performance Measurement and Auditing Andrew Williamson and Alfred D. Vella . . . . . . . . . . . . 37

5 Coordinating Change Through Effective Communication at England's Newest University Hilary Duckett . . . . . . . . . . . . . . . . . . 41

6 The Simulation of Taiwan's Power Generation System Alfred D. Vella and Chuing-Yao Chen . . . . . . . . . . . 49

7 Performance Measurement, Goal Setting and Feedback in Engineering Design J.S. Busby, A. Williamson and G.M. Williams . . . . . . . . 58

8 Using Information Technology to Manage the Change Process in Organisations Alfred D. Vella and Andrew Williamson . . . . . . . . . . . 73 


\section{Theme II: Modelling for Information Systems}

9 Issues in Information Systems Development Models

Ray J. Paul and Robert D. Macredie . . . . . . . . . . . 81

10 The Metaphysical Foundations of Soft and Hard Information Systems Methodologies

Stephen K. Probert . . . . . . . . . . . . . . . . 86

11 Information Systems Intervention: A Total Systems View

Steve Clarke and Brian Lehaney . . . . . . . . . . . . . 103

12 Why Mixed Methods are Necessary to Derive

Enterprise-wide Solutions

D. (Rajan) Anketell .

13 Tailorable Information Systems Add Value to Organisations in Changing Environments

Nandish V. Patel. . . . . . . . . . . . . . . . . . . . 128

14 The Retail Industry and Information Technology

David Shaw and Anne Leeming . . . . . . . . . . . 139

15 Information Systems at the Superstore Interface

Brian J. O'Connor . . . . . . . . . . . . . . . . . 155

\section{Theme III: Modelling for Decision Support}

16 Modelling for Decision Support in Simulation

Ray J. Paul and Robert D. Macredie . . . . . . . . . . . . 161

17 The Strategic Role of Expert Systems in UK Organisations

Elayne W. Coakes and Kim Merchant . . . . . . . . . . 171

18 Workflow Benchmarking for Improved Productivity in a Large Store Group

Anthony R. Ovenden . . . . . . . . . . . . 177

19 Adding Value Through Simulation by Focusing on Process

Brian Lehaney. . . . . . . . . . . . . . . . . 184

20 The Centre for Applied Simulation Modelling

Ray J. Paul. ..................

21 Combining Modelling Approaches in Library Systems Analysis

Jon Warwick and Shamim Warwick . . . . . . . . 206

22 The Usability of User Interfaces to Simulation Systems

Jasna Kuljis . . . . . . . . . . . . . . 215

Subject Index . . . . . . . . . . . . . . . . . . . . . . . . . . . . . 239

Author Index ... . . . . . . . . . . . . 243 


\section{List of Contributors}

D. (Rajan) Anketell

Anketell Management Services Limited, 608 Kingston Road, Raynes Park, London SW20 8DN, UK

Tel: +44 181543 4729; Fax: +44 181543 1801;

e-mail: rajan.anketell@mcmail.com

J.S. Busby

Cranfield University, Cranfield, Bedfordshire MK43 0AL, UK

Chuing-Yao Chen

Power Development Department, Taiwan Power Company, Taipei, Taiwan

Steve Clarke

Department of Business Systems, University of Luton, Park Square, Luton, Bedfordshire LU1 3JU, UK

Tel: +44 1582 734111; Fax: +44 1582 743143;

e-mail: Steve.Clarke@Luton.ac.uk

Elayne W. Coakes

Westminster Business School, University of Westminster, Well Street, London W1P 3FG, UK

Hilary Duckett

Oxford Brookes University, School of Business, Wheatley Campus, Wheatley, Oxfordshire OX33 1HX

Tel: +44 1865 485874; e-mail hrduckett@brookes.ac.uk

Jasna Kuljis

Department of Mathematical and Computing Sciences, Goldsmiths College, University of London, New Cross, London SE14 6NW, UK Tel: +44 171 919 7868; Fax: +44 171919 7853; e-mail: j.kuljis@gold.ac.uk 
Brian Lehaney

Department of Business Systems, University of Luton, Park Square, Luton, Bedfordshire LU1 3JU, UK

Tel: +44 1582 734111; Fax: +44 1582 743143;

e-mail: Brian.Lehaney@Luton.ac.uk.

Anne Leeming

Department of Management Systems and Information, City University Business School, Barbican Centre, London EC2Y 8HB,UK

e-mail: A.Leeming@city.ac.uk

Anthony Lucas-Smith

Design and Innovation Discipline, The Open University, Walton Hall, Milton Keynes MK7 6AA, UK

Tel: +44 1908 655022; Fax: +44 1908 654052;

e-mail: a.j.h.lucas-smith@open.ac.uk

Robert D. Macredie

Department of Information Systems and Computing, Brunel University, Uxbridge, Middlesex UB8 3PH, UK

Tel: +44 1895 203374; Fax: +44 1895 203391;

e-mail: Robert.Macredie@brunel.ac.uk

Kim Merchant

University of Luton, Park Square, Luton, Bedfordshire LU1 3JU, UK

Brian J. O'Connor

B J. O'Connor International Ltd, 10 Aldenholme, Ellesmere Road, Weybridge, Surrey KT13 0JF, UK

Tel: +44 1932 851334; Fax: +44 1932854298

Anthony R. Ovenden

22 Tower Road, Tadworth, Surrey KT20 5QY, UK

Ray J. Paul

Department of Information Systems and Computing, Brunel University, Uxbridge, Middlesex UB8 3PH, UK

Tel: +44 1895 203374; Fax: +44 1895 203391;

e-mail: Ray.Paul@brunel.ac.uk

Nandish V. Patel

Department of Information Systems and Computing, Brunel University, Uxbridge, Middlesex UB8 3H, UK

Stephen K. Probert

School of Computing and Information Systems Management, Cranfield University, RMCS Shrivenham, Swindon, Wiltshire SN6 8LA, UK

Tel: +44 1793 785738; Fax: +44 1793 782753;

e-mail: s.k.probert@rmcs.cranfield.ac.uk 
Carl Sandom

Department of Information Systems and Computing, Brunel University, Uxbridge, Middlesex, UB8 3PH, UK

Tel: +44 1895 203374; Fax: +44 1895203391

David Shaw

Department of Management Systems and Information, City University Business School, Barbican Centre, London EC2Y 8HB,UK

e-mail: d_shaw@compuserve.com

Alfred D. Vella

University of Luton, Park Square, Luton, Bedfordshire LU1 3JU, UK e-mail: alfred.vella@luton.ac.uk

Jon Warwick

School of Computing, Information Systems and Mathematics, South Bank University, 103 Borough Road, London SE1 0AA, UK

Shamim Warwick

University of Luton, Park Square, Luton, Bedfordshire LU1 3JU, UK

G.M. Williams

Cranfield University, Cranfield, Bedfordshire MK43 OAL, UK

Andrew Williamson

Cranfield University, Cranfield, Bedfordshire MK43 0AL, UK

e-mail: A.S.Williamson@Cranfield.ac.uk 